\title{
Journal Club: Width and neurophysiologic properties of tissue bridges predict recovery after cervical injury
}

Seth Disano Holland

Neurology ${ }^{\circledR}$ 2020;94:e1961-e1963. doi:10.1212/WNL.0000000000008941
Correspondence

S.D. Holland

Seth.Holland@alumni.ubc.ca
Long-term functional recovery following spinal cord injury (SCI) is difficult to prognosticate accurately. ${ }^{1}$ Spontaneous neurologic recovery occurs in some but not all cervical lesions that are initially classified as complete. ${ }^{2}$ The ability to predict the likelihood of recovery is of obvious value for the individual who has sustained an SCI, and in stratifying patients for clinical trials. ${ }^{3} \mathrm{~A}$ greater total width of spared tissue is correlated with improved functional outcomes. ${ }^{4}$ A recent study by Vallotton et al. ${ }^{5}$ takes advantage of the anatomical segregation of sensory and motor pathways along the spinal cord to demonstrate the utility of considering individual widths of the dorsal and ventral tissue bridges to predict sensory and motor recovery independently.

\section{Hypothesis and design}

The authors wanted to determine if there was a correlation between the individual dorsal or ventral tissue bridge widths with sensory or motor electrophysiologic measurements, sensory or motor clinical recovery, and functional independence.

\section{Methods}

T2-weighted midsagittal MRI scans were obtained at approximately 1 month (35.3 days \pm 16 ) following initial injury. This allowed for the resolution of obfuscating edema or hemorrhage, providing a quantifiable image of the tissue bridges. Hyperintense signals were classified as the lesion and Jim 6.0 software was used to measure the width of the tissue bridges. At 1 (28 days \pm 7 ) and 12 (371 days \pm 5$)$ months, clinical sensory and motor scores were obtained using the International Standards for Neurologic Classification of SCI (INSCI), ${ }^{6}$ and functional independence was quantified with the commonly used spinal cord independence measure (SCIM). ${ }^{7}$ This provided the opportunity to correlate the short-term tissue bridge width with long-term functional recovery.

Sensory evoked potentials (SEPs) and motor evoked potentials (MEPs) were measured 3 months (87.19 days \pm 12 ) post SCI according to standard European Multicenter Study about Spinal Cord Injury protocol. ${ }^{8}$ SEPs were obtained by tibial nerve stimulation and the cortical response was measured at $C z^{\prime}$. MEPs were collected using transcranial magnetic stimulation 4 $\mathrm{cm}$ rostral to $\mathrm{Cz}$ and measured at the abductor hallucis. These measurements allowed for the calculation of SEP and MEP latencies and amplitudes; both are informative to the conductance of spared spinal cord tissue. Peripheral nerve damage, which would interfere with SEP and MEP measurements, was assessed by distal and proximal stimulation of the tibial nerve.

\section{Results}

Of the 28 patients included, 25 were found to have at least one (dorsal or ventral) tissue bridge, 19 of whom had both. Patients classified as sensory incomplete (American Spinal Injury 
Association Impairment Scale [AIS] grade B-D) at 12 months had an average larger dorsal tissue bridge at 1 month than those classified as sensory complete (AIS grade A) $(\mathrm{n}=$ $27, p=0.025$; AIS A, $0.1 \mathrm{~mm} \pm 0.2$, AIS B-D, $1.2 \mathrm{~mm} \pm 1$ ). Similarly, patients classified as motor incomplete (AIS grade B-D) at 12 months had an average larger ventral tissue bridge respectively at 1 month than those classified as motor complete (AIS grade A) $(\mathrm{n}=27, p=0.002$; AIS grade $\mathrm{A}-\mathrm{B}$, $0.21 \mathrm{~mm} \pm 0.4$; AIS grade $\mathrm{C}-\mathrm{D}, 1.46 \mathrm{~mm} \pm 1$ ).

Wider dorsal tissue bridges at 1 month correlated with greater SEP amplitude $(\mathrm{n}=26, r=0.61, p=0.001)$ and shorter SEP latencies ( $\mathrm{n}=18, r=-0.57, p=0.016)$ at 3 months postinjury. Dorsal tissue bridge width was also correlated with better clinical sensory function (light touch but not pinprick scores) ( $\mathrm{n}=26, r=0.40, p=0.045)$ and functional independence at 12 months post $\mathrm{SCI}(\mathrm{n}=26, r=0.59, p=0.001)$. Notably, this was independent of ventral tissue bridge width and clinical sensory scores at 1 month post SCI.

Wider ventral tissue bridges at 1 month correlated with greater MEP/compound muscle action potential amplitude ratios $(\mathrm{n}=25, r=0.56, p=0.035)$ and shorter MEP latencies ( $\mathrm{n}=15, r=-0.54, p=0.044)$ at 3 months postinjury. Ventral tissue bridge width was also correlated with better clinical motor function (lower extremity motor score) $(\mathrm{n}=27, r=$ $0.41, p=0.035)$ and functional independence at 12 months post SCI $(\mathrm{n}=25, r=0.44, p=0.028)$. Again, this was independent of dorsal tissue bridge width and clinical motor scores at 1 month post SCI.

\section{Interpretation}

The study by Vallotton et al. ${ }^{5}$ retrospectively measured the width of dorsal and ventral tissue bridges on either side of the posttraumatic cyst and their correlation with long-term recovery. The authors show how MRI data taken at 1 month post SCI can be useful in determining relevant functional outcomes at 3 and 12 months post SCI. They also demonstrated the independence of each tissue bridge to the opposing sensory or motor recovery.

To the study's strength, the authors employed a number of measures to determine function following SCI, including electrophysiologic evoked potentials, clinical assessments, and independence scores. Because of the variety of measures used when correlations between tissue bridge width and function were determined, the multiple lines of evidence bolstered the authors' findings. In addition, the methods used (INSCI examination, MEP/SEP electrophysiology, and SCIM measure) are wellestablished, well-described, and common among SCI researchers, allowing for reproduction and comparison to subsequent studies.

The study was conducted using 6 different scanners with both $1.5 \mathrm{~T}$ and $3 \mathrm{~T}$ magnets. There was no discussion as to whether the differences in scanners or magnet strength affected the ability to accurately measure the tissue bridge dimensions or if there were any differences in tissue bridge dimension variability between scanners. Because the impact of this study hinges on the ability of other centers to accurately measure these fine aspects of spinal cord anatomy, a section discussing reproducibility and the required technical ability would have been welcome.

The statistical tools used by the authors tested for whether AIS grading (at 1 year) had significantly different tissue bridge widths (at 1 month) and whether wider widths were correlated to better functional outcomes. These do not allow for a prediction of the likelihood of improvement, which would be of greater value for prognostication. Linear discriminant analysis is a tool that can be used to predict the probability of a given outcome when the possible outcomes are discrete categories. Linear discriminant analysis could have been used to predict the chances of AIS grade conversion or to predict the eventual AIS score at 12 months using 1-month tissue bridge widths. ${ }^{9}$

The common assumption that the spinal cord has a strict dorsalis-sensory and ventral-is-motor organization proved useful in this study, although a more detailed understanding of the spinal cord anatomy may ultimately be more informative. In reality, sensory tracts are not always found dorsally and motor tracts are not always found ventrally (e.g., the lateral corticospinal and ventral spinothalamic tract). ${ }^{10}$ These dorsal-motor and ventral-sensory tracts could be contributing to the tissue bridges and are worth consideration. In addition, there are several important motor and sensory tracts that are laterally distributed, and a midsagittal scan would exclude these pathways. Alternatively, obtaining a $3 \mathrm{D}$ volume may be more informative to assessing the extent of the lesion, the amount of spared tissue, and therefore the likelihood of functional recovery.

The patient demographics reported by the authors include age at injury, sex, and neurologic level of injury, although data on the mechanism of injury are absent. The authors suggest that the mechanism of injury is the main determinant of tissue sparing. Reporting the mechanism of injury in the patient demographic data would allow for a statistical analysis of whether the mechanism of injury is related to tissue bridge size or a predictor of recovery itself. In addition, the authors conclude that functional outcomes were independent of age or sex, which contradicts a number of studies. To bolster the strength of this surprising finding, the authors could have included a larger sample size, systemically divided the patient pool into groups based off of both age and sex, and run their analyses independently in each group. Also of note is the broad exclusion criteria, which provides an opportunity to inadvertently introduce bias by excluding patients whose spared tissue width may not predict recovery.

One finding of interest is that dorsal tissue bridge width only predicted the recovery of one sensory modality: light touch. Recovery of pain sensation was independent of the amount of spared dorsal tissue at the lesion site. Light touch and pain are coded by different receptors and transmit information to 
processing centers along separate anatomical pathways. The dorsal columns (fasciculus gracilis and fasciculus cuneatus) carries vibration, proprioceptive, and fine touch information, whereas the lateral spinothalamic tract (located adjacent to the ventral motor horns) transmits temperature and pain modalities. The anatomical separation of dorsally located light touch tracts and ventrally located pain tracts likely explains why spared dorsal tissue did not predict recovery of pain sensation (pinprick) but did predict light touch recovery.

Vallotton et al. ${ }^{5}$ show how measuring the individual widths of dorsal and ventral tissue bridges at 1 month following injury can be used to separately consider the long-term sensory or motor outcomes. This adds a further degree of detail for clinicians to take advantage of when trying to determine the likelihood and extent of recovery. This valuable study lays the groundwork for future research to determine the probability of long-term AIS grades given tissue bridge widths at 1 month.

\section{Acknowledgment}

The author thanks Matt S. Ramer, PhD, University of British Columbia, for critical review of the manuscript.

\section{Study funding}

No targeted funding reported.

\section{Disclosure}

S.D. Holland reports no disclosures relevant to the manuscript. Go to Neurology.org/N for full disclosures.

\section{References}

1. Fawcett JW, Curt A, Steeves JD, et al. Guidelines for the conduct of clinical trials for spinal cord injury as developed by the ICCP panel: spontaneous recovery after spinal cord injury and statistical power needed for therapeutic clinical trials. Spinal Cord 2007;45:190-205.

2. Steeves JD, Kramer JK, Fawcett JW, et al. Extent of spontaneous motor recovery after traumatic cervical sensorimotor complete spinal cord injury. Spinal Cord 2011;49: 257-265.

3. Burns AS, Lee BS, Ditunno JF Jr, Tessler A. Patient selection for clinical trials: the reliability of the early spinal cord injury examination. J Neurotrauma 2003;20: $477-482$.

4. Huber E, Lachappelle P, Sutter R, Curt A, Freund P. Are midsagittal tissue bridges predictive of outcome after cervical spinal cord injury? Ann Neurol 2017;81:740-748.

5. Vallotton K, Huber E, Sutter R, Curt A, Hupp M, Freund P. Width and neurophysiologic properties of tissue bridges predict recovery after cervical injury. Neurology 2019;92:e2793-e2802.

6. Kirshblum SC, Burns SP, Biering-Sorensen F, et al. International standards for neurological classification of spinal cord injury (revised 2011). J Spinal Cord 2011: 535-546.

7. Catz A, Itzkovich M, Agranov E, Ring H, Tamir A. SCIM: spinal cord independence measure: a new disability scale for patients with spinal cord lesions. Spinal Cord 1997; $35: 850-856$.

8. Curt A, Van Hedel HJ, Klaus D, Dietz V. Recovery from a spinal cord injury: significance of compensation, neural plasticity, and repair. J Neurotrauma 2008;25: $677-685$.

9. Kwon BK, Streijger F, Fallah N, et al. Cerebrospinal fluid biomarkers to stratify injury severity and predict outcome in human traumatic spinal cord injury. J Neurotrauma 2017;34:567-580.

10. Bican O, Minagar A, Pruitt AA. The spinal cord: a review of functional neuroanatomy. Neurol Clin 2013;31:1-18. 


\section{Neurology}

\section{Journal Club: Width and neurophysiologic properties of tissue bridges predict recovery after cervical injury \\ Seth Disano Holland}

Neurology 2020;94;e1961-e1963 Published Online before print January 28, 2020

DOI 10.1212/WNL.0000000000008941

This information is current as of January 28,2020

\section{Updated Information \&} Services

References

Subspecialty Collections

Permissions \& Licensing

Reprints including high resolution figures, can be found at: http://n.neurology.org/content/94/18/e1961.full

This article cites 9 articles, 1 of which you can access for free at: http://n.neurology.org/content/94/18/e1961.full\#ref-list-1

This article, along with others on similar topics, appears in the following collection(s):

\section{MRI}

http://n.neurology.org/cgi/collection/mri

Spinal cord trauma

http://n.neurology.org/cgi/collection/spinal_cord_trauma

Spinal cord trauma; see Trauma/spinal cord trauma

http://n.neurology.org/cgi/collection/spinal_cord_trauma-see_trauma-s pinal_cord_trauma

Information about reproducing this article in parts (figures,tables) or in its entirety can be found online at:

http://www.neurology.org/about/about_the_journal\#permissions

Information about ordering reprints can be found online:

http://n.neurology.org/subscribers/advertise

Neurology ${ }^{\circledR}$ is the official journal of the American Academy of Neurology. Published continuously since 1951, it is now a weekly with 48 issues per year. Copyright @ 2020 American Academy of Neurology. All rights reserved. Print ISSN: 0028-3878. Online ISSN: 1526-632X.

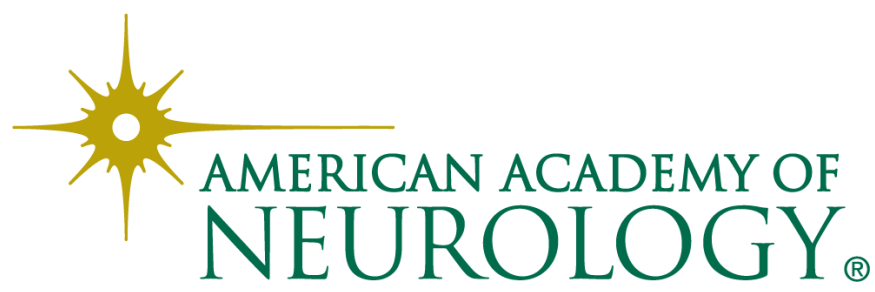

